Matatam Vivivesity - Master of Management gournal

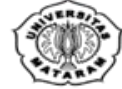

\title{
PENGARUH BERANTAI BUDAYA ORGANISASI DAN HUMAN RESOURCE PRACTICES TERHADAP KREATIFITAS DAN KINERJA USAHA UMKM
}

\section{Sulhaini ${ }^{1}$, Rusdan ${ }^{2}$, Rahman Dayani ${ }^{3}$, Baiq Ismiwati ${ }^{4}$}

${ }^{1}$ Faculty of Economics and Business, Mataram University, E-mail: sulhaini@unram.ac.id

${ }^{2}$ Faculty of Economics and Business, Mataram University, E-mail: erdanmuslim@gmail.com

${ }^{3}$ Faculty of Economics and Business, Mataram University, E-mail: rahmandayani@gmail.com

${ }^{4}$ Faculty of Economics and Business, Mataram University, E-mail: ismiwati2010@gmail.com

\begin{tabular}{|c|c|}
\hline ARTICLE INFO & ABSTRACT \\
\hline $\begin{array}{l}\text { Keywords: } \\
\text { human resource practices, } \\
\text { organizational culture, creativity } \\
\text { How to cite: } \\
\text { Sulhaini, Rusdan, Dayani, R, Ismiwati, } \\
\text { B., (2018). Pengaruh Berantai Budaya } \\
\text { Organisasi Dan Human Resource } \\
\text { Practices Terhadap Kreatifitas Dan } \\
\text { Kinerja Usaha UMKM. JMM } \\
\text { UNRAM, 7(3), } 61 \text { - } 77 \\
\text { DOI : } \\
\text { 10.29303/jmm.v7i3.334 }\end{array}$ & $\begin{array}{l}\text { This research aimed at examining the chain of effects of } \\
\text { organisational culture and human resource practices } \\
\text { towards SMEs' creativity and performance. The study } \\
\text { contributes to the literature by giving explanations related } \\
\text { to how human resource practices, market and learning } \\
\text { orientations affect the creativity and performance of SMEs. } \\
\text { Population in this research was all SMEs producing } \\
\text { handicraft, food / beverage and others in Mataram- } \\
\text { Indonesia. Sample firms were selected using purposive } \\
\text { sampling. The results showed that organizational culture, } \\
\text { namely market orientation and learning orientation affect } \\
\text { creativity and business performance in different ways. } \\
\text { Learning orientation does not have a strong effect on } \\
\text { creativity but has a direct effect on business performance. } \\
\text { Meanwhile market orientation and human resource practices } \\
\text { have no direct effect on business performance but through } \\
\text { their influence on creativity. Market orientation and human } \\
\text { resource practices ensure high business performance through } \\
\text { its influence on creativity improvement. Market orientation } \\
\text { becomes a source of creative ideas as its dimensions provide } \\
\text { opportunities for SMEs to find useful ideas. Furthermore, } \\
\text { human resource practices maintain / motivate employees for } \\
\text { continuous creative endeavors, faster and better than to } \\
\text { competitors. This creates higher customer value, stronger } \\
\text { competitive advantage and greater guarantees business } \\
\text { success /business performance. } \\
\text { Penelitian ini menguji pengaruh berantai dari budaya } \\
\text { organisasi dan human resource practices terhadap kreatifitas }\end{array}$ \\
\hline
\end{tabular}




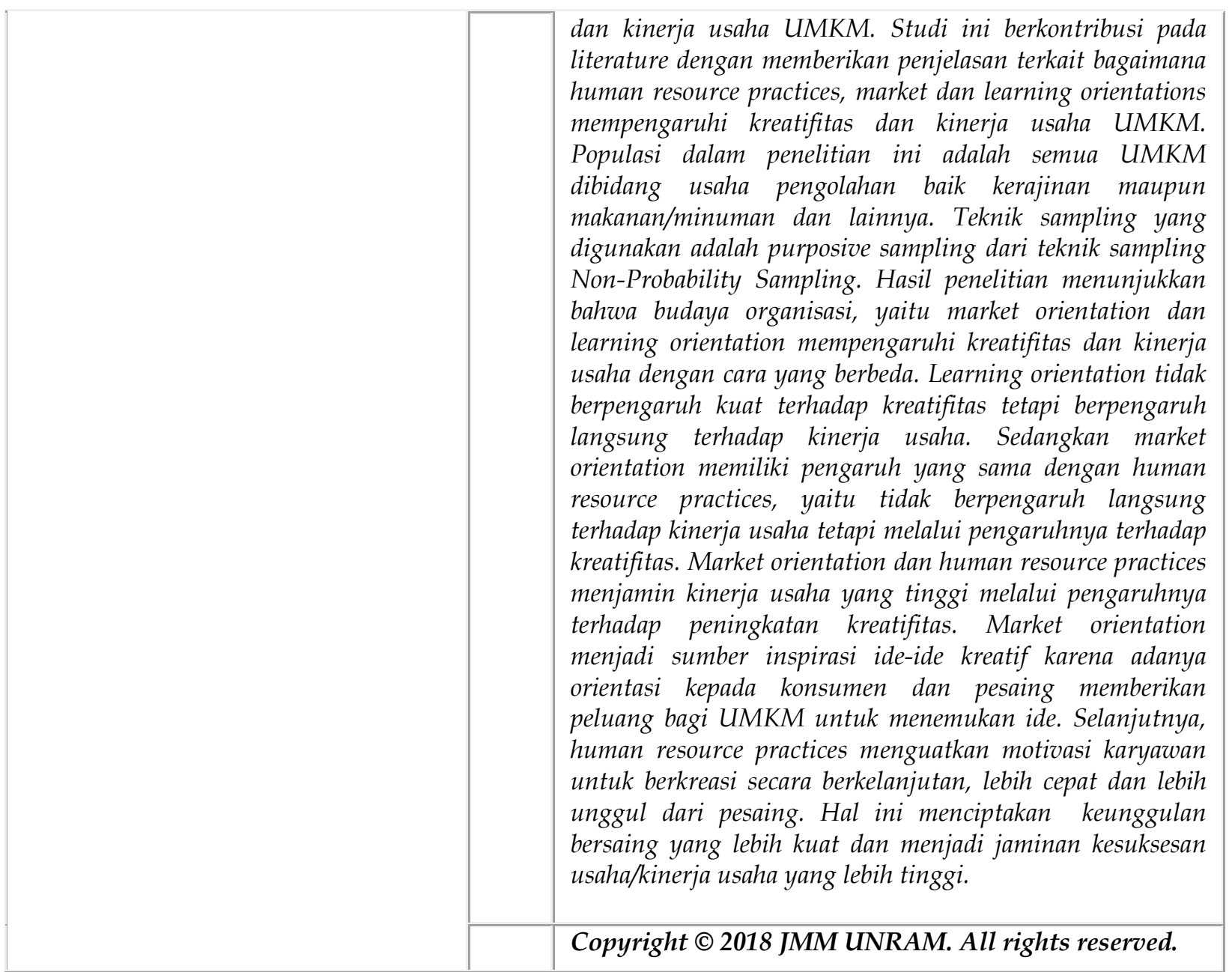

\section{INTRODUCTION}

Kreatifitas merupakan kunci sukses untuk menjamin proses inovasi (Hirst et al., 2009), bahkan kreatiftas adalah titik awal dalam proses inovasi dan sebuah perusahaan tidak dapat dikatakan inovatif apabila tidak kreatif. Sehingga dapat dikatakan pula bahwa kreatifitas adalah elemen utama dalam proses inovasi (Hansen et al., 2011). Walaupun peranan kreatifitas sangat penting, namun study terkait ini masih dalam tahapan sangat awal, sementara itu study terkait inovasi sudah sangat banyak. Inovasi sendiri merupakan implementasi dari kreatifitas (ḉokpekin and Knudsen, 2012) dan keduanya merupakan dimensi utama dari entrepreneurial orientation (EO). Kreatifitas telah dipandang sebagai proses di mana karyawan perusahaan mampu mengeluarkan ide-ide yang unik dan bermakna demi kesuksesan perusahaan (Amabile, 1988). Proses kreatif memerlukan modal manusia sebagai sumber daya yang paling utama karena hanya merekalah yang mampu belajar dan beradaptasi agar kemampuan dan pengetahuannya berkembang untuk menciptakan nilai optimal bagi pelanggan (Nasution \& Mavondo, 2008). Meningkatkan kreatifitas mereka menjadi semakin penting bagi perusahaan di saat persaingan yang semakin tajam. 


\section{Jurnal Magister Manajemen Unram ～Vol. 7, No 3. September 2018 \\ NATIONALY ACCREDTED JOURNAL - DECREE NO. 21/E/KPT/2O18}

Perusahaan kecil maupun besar dihadapkan pada tantangan dengan perubahan selera konsumen yang sangat dinamis, disamping itu mereka menghadapi berbagai kendala internal dalam upaya mengembangkan pemikiran kreatif karyawan. Dalam economi kreatif, perusahaan harus tetap kompetitif dengan meningkatkan kreatifitas karyawan. Dengan demikian, strategi human resource practice dengan membangun tim kerja, sistem pengupahan dan pelatihan merupakan strategi penting untuk menumbuhkan kreatifitas karyawan (Muñoz-Doyage and Nieto, 2012). Komitmen perusahaan untuk mengembangkan kreatifitas adalah dengan menerapkan strategi yang diarahkan untuk menumbuhkan kreativitas dimana karyawan secara mandiri berkreasi dan berinovasi.

Kreatiftas karyawan secara umum dipandang sebagai penentu kinerja tugas dan perusahaan, akan tetapi penelitian terdahulu tidak memberikan bukti empiris yang jelas (Gong et al., 2009). Tampaknya kreatifitas merupakan konstruk yang tidak dipahami secara mendalam dan bagaimana human resource practices seperti training and reward systems menentukan kreatiftas dan kinerja perusahaan belum sepenuhnya dijelaskan dalam literatur pemasaran (Suh et al., 2010; Burroughs et al., 2011). Hal ini dapat disebabkan oleh kenyataan bahwa kreatifitas merupakan sumber daya kritis yang intangible (Im et al., 2013). Kreatifitas perusahaan kecil dalam pengembangan produk dan kegiatan pemasarannya harus kuat untuk dapat bersaing dengan perusahaan yang lebih besar dan kuat. Namun sayangnya, kegiatan-kegiatan kreatif lebih banyak diteliti di perusahaan besar dan memberi kesan bahwa kegiatan kreatif hanya dilakukan oleh perusahaan besar saja (Burroughs et al., 2011). Penelitian-penelitian terdahulu hanya mengungkap kreatifitas karyawan di perusahaan besar sedangkan perusahaan kecil memiliki sumber daya terbatas yang biasanya terbatas pula dalam kegiatan kreatif kurang mendapat perhatian pada penelitian sebelumnya (Cropley et al., 2011). Dengan demikian, studi ini akan menguji kegiatan kreatif di kalangan UMKM dan akan berkontribusi pada literatur dengan memberikan penjelasan terkait bagaimana human resource practices dan budaya organisasi mempengaruhi kreatifitas dan kinerja usaha UMKM. Tujuan dari penelitian ini adalah untuk mengisi celah literature sebagaimana telah diuraikan di atas dengan menguji pengaruh berantai dari budaya organisasi dan human resource practices terhadap kreatifitas dan kinerja usaha UMKM.

\section{LITERATURE REVIEW}

\subsection{Learning orientation}

Budaya organisasi yang menekankan pada proses organisational learning dapat memacu kreatifitas dan inovasi. Organisasi yang kreatif dan inovatif adalah organisasi yang mengutamakan belajar di mana proses belajar tidak hanya pada tingkat individu tetapi juga di tingkat organisasi mendorong pengembangan keahlian setiap personil (Trigo, 2013). Learning orientation (LO) telah dipandang sebagai budaya organisasi yang terdiri dari tiga dimensi utama, yaitu commitment to learning, shared vision and open-mindedness (Sinkula et al., 1997). Dimensi pertama memudahkan mekanisme organisational learning di mana pengetahuan yang dimiliki individu dapat ditransfer ke anggota yang lain. Dalam hal ini komunikasi internal dapat meningkatkan kemampuan belajar dan keahlian serta kreatifas mereka dan organisasi. Learning orientation ditemukan berpengaruh secara positif terhadap tingkat kreatifitas perusahaan (Wang et al. 2008). Akan tetapi, Hirst et al (2009) menunjukkan bahwa hasil penelitian yang dipublikasikan terkait pengaruh antar kedua konstruk 


\section{Jurnal Magister Manajemen Unram}

\section{Vol. 7, No 3. September 2018}

NATONALY ACCREDTED JOURNAL - DEEREE NO. 21/E/KPT/2018

tersebut masih sangat sedikit sehingga penjelasan tentang bagaimana belajar dapat berpengaruh terhadap kreatifitas masih terbatas.

Learning orientation memberikan arahan dan dorongan bagi perusahaan untuk mengeksplorasi ide-ide baru tidak hanya untuk inovasi produk tertapi juga pendekatan baru dalam memasarkan produk tersebut. Orientasi tersebut membawa perusahaan secara proaktif belajar tentang konsumennya/pasarnya. Perusahaan dapat mengandalkan berbagai mekanisme untuk mendapatkan pengetahuan yang berguna untuk pengembangan produk baru dan strategi pemasaran. Dalam hal ini LO dipandang dapat menentukan munculnya ide-ide dan pendekatan kreatif (Wang et al., 2008). Dalam hubungan yang erat dengan konsumen, perusahaan dapat belajar dari tuntutan konsumen dan menghasilkan ide-ide kreatif yang dapat ditransformasikan menjadi produk produk yang bernilai bagi konsumen. Perusahaan yang berorientasi learning akan mengevaluasi dan menyesuaikan tawarannya untuk memecahkan masalah konsumen. Pengetahuan tentang konsumen dapat memicu perusahaan untuk memberikan solusi kreatif. LO sebagai budaya organisasi membantu perusahaan untuk mengadaptasikan tawarannya, memadukan dan menggunakan sumber daya yang dimilikinya termasuk pengetahuan tentang konsumen untuk menciptakan nilai peanggan yang optimal untuk kinerja usaha yang lebih baik. Hasil penelitian yang dilakukan oleh Barrett et al (2005) pada organisasi nir laba memberikan petunjuk kreatifitas ditentukan oleh learning orientation. Kedua konstruk tersebut dikelola dan konrtol oleh manajer. Organisasi nir laba harus secara berkelanjutan belajar entitas pasar dan menggunakan pengetahuan tersebut sebagai titik awal untuk aktifitas-aktifitas yang berujung pada meningkatnya kreatifitas. Kharakteristik internal dan kapabilitas organisasi adalah faktor internal yang mendorong tingkat kreatifitas perusahaan. Faktor-faktor tersebut mendorong dan menekankan pada berbagi pengetahuan antar staf dan berbagi ide-ide secara bebas dimana hal ini diyakini dapat memicu pengembangan kreatifitas (Alves et al., 2007). Lebih lanjut, Gong et al., (2009) dan Hirst et al. (2011) memiliki padangan bahwa LO memotivasi karyawan untuk mendapatkan pengetahuan baru dan mencari aktifitas kreatif dan pemecahan masalah dengan berpartisipasi secara aktif dalam proses belajar. Perusahaan dengan orientasi belajar yang kuat terdiri dari orang-orang yang berorientasi kuat pada proses belajar, mereka mencari tantangan untuk mendapatkan peluang belajar sehingga mereka dapat memperoleh experiential knowledge dan keahlian kreatif yang lebih tinggi. Dengan demikian LO dapat memacu perhatian perusahaan untuk pengembangan keahlian kreatif karyawan. Ini menunjukkan bahwa perusahaan dengan LO yang kuat akan memiliki sumber daya manusia yang berorientasi pada belajar di mana perilaku belajarnya dapat memacu kreatifitasnya, akan tetapi hubungan antara LO dengan kreatifitas tidak selalu linier (Hirst et al., 2011) dan perusahaan perlu waktu prgan tung pada kondisi yang dihadapi perusahaan Hipetosa-hipotesa berikut dapat diajukan.

\section{H1: Semakin kuat learning orientation semakin tinggi kreatifitas UMKM H2: Semakin kuat learning orientation semakin tinggu kinerja UMKM}

\subsection{Market Orientation}

Sebagaimana learning orientation, market orientation juga dipandang sebagai budaya organisasi yang menekankan pada pencapaian terciptanya keuntungan dan menjaga nilai pelanggan yang superior serta membangun norma-norma bagi perilaku individu dan respon perusahaan terhadap 


\section{Jurnal Magister Manajemen Unram}

informasi pasar (Slater and Narver, 1995). Orientasi ini menekankan pada kemampuan perusahaan untuk menghasilkan, menyebarkan dan bereaksi terhadap pengetahuan pasar dan berujung pada munculnya ide-ide kreatif dan nilai bagi konsumen (Im et al., 2008).

Market orientation mempunyai tiga dimensi yaitu: customer orientation, competitor orientation dan inter functionnal coordination (Slater and Narver, 1995). Dimensi pertama meningkatkan pemahaman perushaan terhadap konsumen yang dibidiknya agar dapat secara berkelanjutan mengembangkan nilai pelanggan yang superior bagi mereka. Dimensi kedua mengarahkan perusahaan untuk memahami kekuatan, kelemahan, kemampuan dan strategi pesaingnya (Im et al., 2008). Selanjutnya dimensi ke tiga dapat memperkuat kemampuan perusahaan dalam merespon tuntuntan konsumen dan persaingan yang pada akhirnya mendorong kemampuan kreatifitas perusahaan. Dalam hal ini terlihat bahwa pengembangan kreatifitas perusahaan sebagai respon terhadap tuntutan konsumen dan persaingan. Bilamana hubungan internal dan adanya integrasi antar individu, tim dan fungsi-fungsi akan memudahkan distribusi dan penerimaan ide-ide baru secara menyeluruh di dalam perusahaan. Hal ini akan membantu berkembangnya kreatifitas perusahaan (Alves et al., 2007).

Ketiga dimensi dari orientasi ini membantu perusahaan untuk menyadari munculnya ancaman dan peluang yang muncul dari tuntutan konsumen dan perubahan strategi pesaing yang membuat lingkungan persaingan yang semakin dinamis. Orientasi ini pula yang membantu perusahaan untuk membangun respon yang effektif dengan mengintegrasikan semua karyawan/tim/fungsi perusahaan dengan mendorong mereka untuk lebih proaktif terhadap dinamika lingkungan pasar. Dengan orientasi pasar yang kuat, sebuah perusahaan mampu membangun intelijen pasarnya lebih dari sekedar memenuhi kebutuhan konsumen tetapi mampu menciptakan nilai pelanggan yang superior (Nasution and Mavondo, 2008).

Berdasarkan hasil penelitian, Barrett et al (2005) menyatakan bahwa semua dimensi dari orientasi ini menyediakan rute kritis bagi kreatifitas perusahaan dan peningkatan kinerja. Temuan dari penelitian yang dilakukan oleh Im et al. (2008) juga menunjukkan bahwa kesemua dimensi tersebut dapat menjamin tercapaianya peningkatan kreatifitas. Lebih lanjut mereka mengingatkan bahwa pengaruh sinergi antar ketiga dimensi tersebut tidak dapat dipastikan. Ini menyiratkan bahwa perlu penelitian lanjutan terkait dengan orientasi ini.

Penelitian-penelitian terdahulu pada umumnya menemukan bahwa orientasi ini berpengaruh kuat terhadap kinerja usaha. Market orientation memberikan alat bagi perusahaan supaya lebih proaktif dalam mendeteksi dan memonitor lingkungan persaingan agar dapat secara kreatif memuaskan pesaingnya. Orientasi ini menunjukkan tingkat kecepat tanggapan perusahaan dalam memuaskan konsumennya secara lebih efektif dan efisien dari pesaing sehingga menghasilkan kinerja yang lebih baik. Ini berarti bahwa orientasi ini mengarahkan perusahaan untuk mendapatkan pengetahuan dan bahwa ide-ide untuk inovasi dapat berasal dari konsumen agar tidak ada ide yang tidak tepat diimplemensikan sebagai inovasi Secara singkat, market orientation mempengaruhi kinerja usaha (Grinstein, 2008). Hal ini disebabkan karena orientasi tersebut dapat mendorong komitmen perusahaan terhadap konsumennya. Komitmen tersebut terlihat dari keinginan perusahaan untuk memperkuat intelijen pasar seagai fondasi bagi kreatifitas dalam produk dan pemasaran untuk memuaskan konsumen dan menjamin kesuksesan penjualan dan kinerja usaha (Baker and Sinkula, 2009). Oleh karena itu, hipotesa berikut dapat dirumuskan. 


\section{Jurnal Magister Manajemen Unram Vol. 7, No 3. September 2018 \\ NATIONALY ACCREDTED JOURNAL - DECREE NO. 21/E/KPT/2O18}

\section{H3: Semakin kuat market orientation semakin tinggi kreatifitas UMKM H4: Semakin kuat market orientation semakin tinggi kinerja UMKM}

\subsection{Human Resource Practices}

Ketersediaan human capital dalam jumlah dan kualitas yang memadai menjadi sangat penting untuk menjamin kesusksesan ide-ide kreatif (Alves et al., 2007). Ketersediaan ini menuntut perusahaan membangun strategi yang tepat untuk membangun mekanisme-mekanisme organisasional untuk mendorong dan memotivasi karyawannya. Hal ini semakin dirasakan penting di tengah perubahan lingkungan bisnis yang semakin dinamis dan kompetitif, siklus hidup produk yang semakin singkat, perusahaan menghadapi tantangan yang semakin keras untuk tetap kompetitif.

Terciptanya ide-ide kreatif dapat ditumbuhkan dan difasilitasi melalui berbagai mekanisme internal. Pertama, kreatifitas dimulai dari mekanisme perekrutan tenaga kerja yang tepat yang menekankan pada kapasitas kreatif dari tenaga kerja (Hsu, 2016). Kedua, mengelola kreatifitas melalui proses identifikasi potensi daya kreatif dari setiap pekerja dan memahami bagaimana mereka bekera dalam tim dan bagaimana hal-hal tersebut dapat mempengaruhi kreatifitas individual. Perusahaan dapat memotivasi individu karyawanya untuk mencari peluang-peluang ataupun menghindari peluang yang tak penting agar proses belajar dan kreatifitas dapat dijamin keberhasilannya (Hirst et al. , 2008). Ketiga, program pelatihan karyawan haruslah menekankan pada penciptaan ide kreatifitas dan daya imaginasi mereka. Empat, program ini dapat meningkatkan kemampuan mereka dalam memecahkan masalah secara kreatif. Program ini yang bila dikombinasikan dengan sistem penghargaan yang tepat akan berdampak pada kapasitas kreatif karyawan yang lebih tinggi (Burroughs et al., 2011).

Perusahaan yang dapat memacu kemampuan kreatif karyawan dan bilamana mereka terlibat dalam proses belajar berarti kreatiftas berkelanjutan terjamin. Perusahaan dapat dikatakan kreatif bilamana perusahaan tersebut memeliki mekanisme untuk memotivasi karyawannya (Amabile, 1988). Sehingga, perusahaan seharusnya menekankan pada pelatihan karyawan dan mekanisme internal untuk mengembangkan pengetahuan dan keterampilan karyawan (Mavondo et al., 2005). Sebuah perusahaan harus mengelola sumber daya dan lingkungan kerjanya dengan memberikan perhatian pada masalah finansial, bahan, pendampingan, dan pelatihan untuk mendorong karyawan untu menghasilkan ide-ide unik untuk produk baru atau pendekatan baru untuk menyelsaikan tugas mereka. Human resource practices menentukan mengapa sebagian perushaan lebih kreatif dan inovatif dari yang lainnya. Praktek tersebut memicu kreatiftas pada level perusahaan dan kinerja usaha (Beugelsdijk, 2008). Dengan demikian dapat dirumuskan hipotesa sebagai berikut :

H5: Semakin baik human resource practices semakin tinggi kreatifitas UMKM

H6: Semakin baik human resource practices semakin tinggi kinerja UMKM

\subsection{Business performance}

Kreatifitas berkaitan dengan bagaimana perusahaan membangun kemampuan teknis untuk menciptakan produk baru dan bagaimana mengkomersialisasikan produk tersebut (Im et al, 2013). Ini menunjukkan bahwa kreatifitas tidak hanya mengenai kemampuan perusahaan dalam menghasilkan ide-ide bagus untuk produk baru tetapi juga tak kalah pentingnya adalah bagaimana 
kreatifitas terlhat dari strategi pemasaran produk baru terebut. Hal ini tentunya untuk menjamin kreatiftas dapat berdampak positi terhadap kinerja pemasaran.

Kreatifitas juga dapat membawa dampak pada diferensiasi produk yang bermakna yang dapat mendukungi positioining, daya saing dan kinerja perusahaan (Im and Workman, 2004). Sehingga bila konsumen mempersepsikan produk-produk yang ditawarkan perusahaan sebagai unik dan lebih baik dari pesaing, itu berarti merupakan hasil dari strategi diferensiasi yang sukses. Strategi ini adalah hasil dari kreatfitas yang kuat dan berdampak pada kinerja usaha yang lebih baik (Suh et al., 2010).

Slater et al. (2010) menyatakan bahwa perusahaan yang kreatif akan memiliki kemampuan yang lebih baik untuk menemukan cara untuk dapat memperoleh dan menikmati keuntungan yang lebih tinggi dari setiap kegiatan pemasarannya. Strategi marketingnya diarahkan kepada penciptaan nilai pelanggan yang unik dan positioning yang efektif. Kemampuan tersebut haruslah unik, jarang dan sulit untuk ditiru, sehingga dapat menjadi sumber daya saing yang berkelanjutan.. Kreatifitas perusahaan dalam menyusun strategi pemasaran semakin penting di saat lingkungan usaha semakin kompetitif dan tidak stabil karena aksi pesaing yang sangat dinamis. Dalam kondisi seperti ini, perusahaan menghadapi perubahan yang sangat cepat pada tuntutan konsumen dan kekuatan/tekanan persaingan. Perusahaan harus lebih kreatif dan mengembangkan strategi pemasaran dalam jangka waktu yang lebih singkat sambil memonitor perkembangan pasar secara kontinyu. Pada tingkat individual karyawan, semakin kreatif karyawan maka semakin baik kinerjanya dan penjualan perusahaan (Gong et al. 2009). Dari uraian diatas, maka dapat diajukan hipotesa sebagai berikut :

\section{H7: Semakin kuat Kreatifitas semakin tinggi kinerja UMKM}

Adapun kerangka konseptual dari penelitian ini digambarkan sebagaimana terlihat pada gambar di bawah ini.

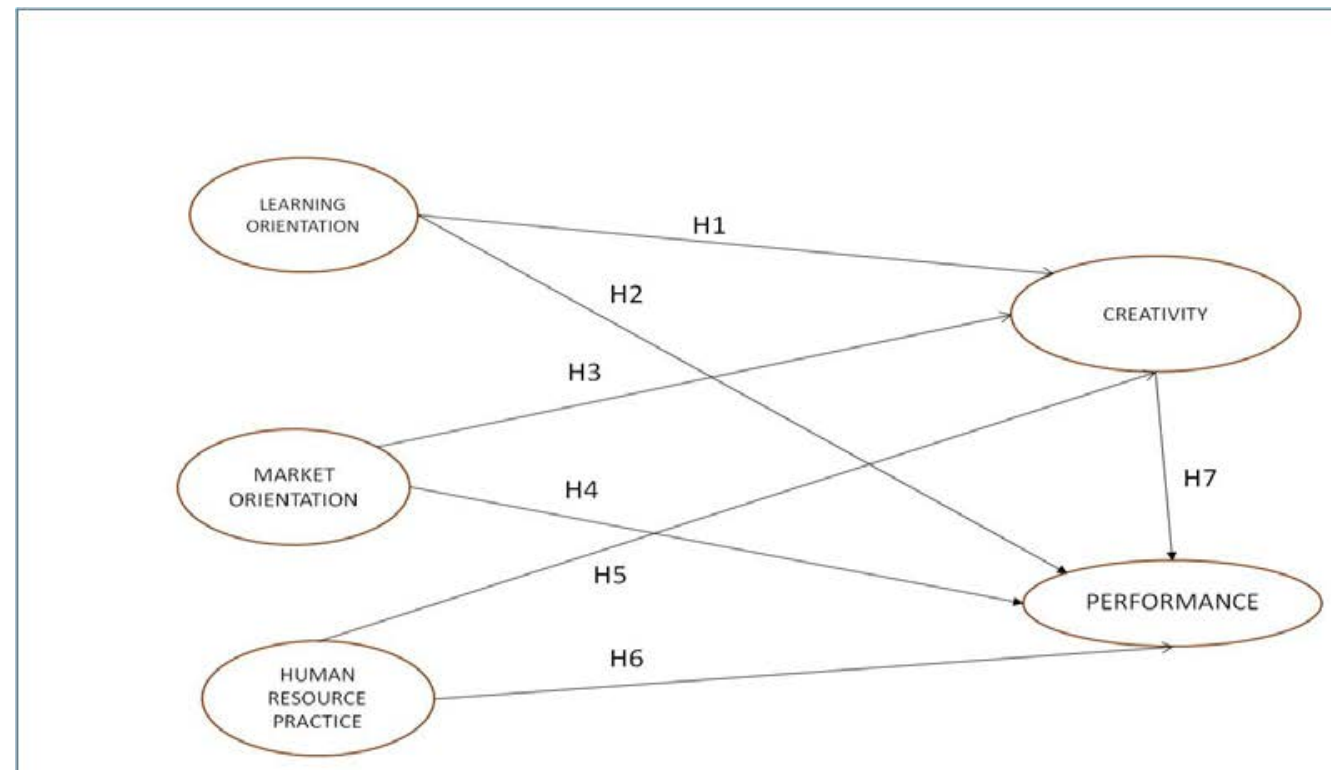




\section{RESEARCH METHOD}

\subsection{Sampling}

Teknik pengambilan sampel yang digunakan dalam penelitian ini adalah purposive sampling dari teknik sampling Non-Probability Sampling. Kriteria yang ditetapkan dalam penelitian adalah para pengusaha yang memiliki minimal lima karyawan. Kriteria ini ditetapkan karena untuk mengukur learning orientation dan market orientation akan berkaitan dengan kerjasama di dalam perusahaan yang melibatkan beberapa orang dari berbagai fungsi/tugas yang berbeda. Adapun karakteristiknya dapat dilihat pada tabel 1.

\subsection{Instrumen Penelitian:}

Learning orientation diukur dengan menggunakan indikator yang telah dikembangkan oleh Wang and Wei (2005). Orientasi ini didefinisikan secara operasional dalam penelitian ini sebagai tanggapan responden tentang bagaimana budaya belajar di dalam perusahaannya dengan tiga indikator, yaitu open mindedness, shared vission dan commitmen on learning. Sementara itu, market orientation dipandang sebagai budaya organisasi, sehingga definisi maupun pengukurannya menggunakan perspektif budaya organisasi. Market orientation didefinisikan sebagai tanggapan responden tentang bagaimana perusahaannya berfokus kepada pasar, konsumen dan pesaingnya dengan melalukan koordinasi internal. Adapun indikator dari orientasi ini adalah: Customer orientation, competitor orientation dan interfunctional coordination (Sanzo et al., 2003). Dimensi-dimensi tersebut pada dasarnya berakar pada pemikiran Slater and Narver (1995) yang dianggap tepat untuk manajemen pemasaran, kinerja usaha, kreatifitas dan inovasi perusahaan (Im et al., 2008). Penelitian-ini mengadopsi item-item pengukuran yang dikembangkan oleh Im and Workman (2004) Selanjutnya, human resource practices menggunakan item pengukuran dari Nasution and Mavondo, 2008). Seluruh kontsruk dalam penelitian ini akan menggunakan seven-point Likert-type scales dengan pilihan sebagai berikut: sangat tidak setuju (1) hingga sangat setuju (7). Adapun peryataan dalam kuesioner akan mengikuti penelitian dari berbagai peneliti sebelumnya sebagaimana diuraikan di atas.

Table 1. Karakteristik sampel

\begin{tabular}{|l|c|c|}
\hline & $\mathrm{N}$ & $\%$ \\
\hline Jumlah tenaga kerja & & \\
$5-10$ orang & 90 & 79,9 \\
$11-30$ orang & 13 & 8,4 \\
$31-50$ orang & 10 & 0,9 \\
51 orang & 1 & \\
\hline Kepemilikan & & 90,4 \\
Milik sendiri & 103 & 7,9 \\
Keluarga & 9 & 1,8 \\
Usaha patungan & 2 & \\
\hline Jenis produk & & 48,2 \\
Kerajinan & 55 & 30,7 \\
Makananm,inuman olahan & 35 & \\
\hline
\end{tabular}

jmm.unram.ac.id 


\begin{tabular}{|l|c|c|}
\hline Lainnya & 24 & 21,1 \\
\hline Umur perusahaan & 38 & 33,3 \\
$<5$ tahun & 32 & 28,1 \\
$6-10$ tahun & 32 & 28,1 \\
$11-20$ tahun & 12 & 10,5 \\
$>21$ tahun & 20 & \\
\hline Umur responden & 30 & 17,5 \\
20 - 30 tahun & 38 & 26,3 \\
$31-40$ tahun & 26 & 33,3 \\
$41-50$ tahun & & 22,8 \\
$>51$ tahun & 62 & 54,4 \\
\hline Nilai penjualan per tahun & 26 & 31,6 \\
$<$ Rp. 100 juta & 7 & 6,1 \\
Rp 101 juta - Rp. 250 juta & 6 & 5,3 \\
Rp. 251 juta - Rp. 500 juta & 3 & 2,6 \\
Rp. 501 juta - Rp 1 milyar & & \\
>Rp 1 milyar & & \\
\hline
\end{tabular}

\section{Hasil uji instrument}

Analisis faktor konfirmatori (CFA/confirmatory factor analysis) digunakan untuk menguji validitas dan reliabilitas skala. Hasil pengukuran ditampilkan pada Tabel 2,di mana semua factor loading lebih besar dari ambang 0,5 (Hair, Black, Babin, Anderson, \& Tatham, 2006); semuanya signifikan pada $\mathrm{p}<0,05$, dan semuanya positif terkecuali item pertama dari customer orientation. Item ini harus dikeluarkan dari instrument.

Analisis juga menunjukkan bahwa nilai-nilai alpha Cronbach dan Composit reliability CR) melebihi nilai cut-off umum 0,70 (Hair, Black, Babin, Anderson, \& Tatham, 2006). Selanjutnya, kami menghitung Average Variance Extracted (AVE) untuk setiap konstruk. Terdapat nilai AVE dibawah ambang batas umum .50 (Hair, Black, Babin, Anderson, \& Tatham, 2006) yaitu untuk kreatifitas dan market orintation, menunjukkan tidak memadainya validitas konvergen. Dukungan untuk reliabilitas dan convergent validity diperoleh dari nilai composit reliability dan alpha cronbach yang nilainya di atas ambang 0,70. Selanjutnya, bukti diskriminant validity dapat dilihat pada tidak adanya item dengan cross loading yang signifikan pada konstruksi lain yang tidak dimaksudkan/relevan. Bila dilihat tabel 2, maka dapat disimpulkan bahwa instrumentnya valid dan reliable. Selanjutnya, confirmatory factor analysis dilakukan untuk menguji instrument, adapan hasilnya adalah sebagai berikut: CMIN/DF: 1,936 GFI: 0.869 GFI: 0.819 RMSR: 0.043 RMSEA : $0.061 \quad$ TLI : $0.925 \quad$ CFI : 0.947. Model tersebut dapat dikatakan layak sehingga instrument layak untuk digunakan. 


\section{Jurnal Magister Manajemen Unram Vol. 7, No 3. September 2018 \\ NATIONALY ACCREDTED JOURNAL - DECREE NO. 21/E/KPT/2O18}

\section{DISCUSSION OF THE ANALYSIS OR RESULTS}

\subsection{Hasil uji model}

Hasil uji model adalah sebagai berikut: CMIN/DF: 1,401 $\quad$ GFI: 0.880 AGFI: 0.810 RMSR: 0.393 RMSEA : 0.060 TLI: 0.882 CFI: 0.905. Hasil uji model tersebut dapat dikatakan layak karena beberapa hasil menunjukkan hasil yang bagus/baik. Hal ini sesuai dengan yang telah disebutkan oleh Widarjono (2010) bahwa model dikatakan layak jika paling tidak salah satu metode uji kelayakan model tersebut terpenuhi karena dalam prakteknya sangat sulit bisa memenuhi semua uji tersebut.

\subsection{Hasil uji hipotesa dan pembahasan}

Setelah melakukan uji ketepatan model dan mendapatkan hasil yang baik, maka dilakukan uji hipotesa dengan hasil terangkum pada Tabel 3. Tabel tersebut menunjukkan bahwa ada 3 dari 7 hipotesa yang tidak terdukung sepenuhnya atau terdukung sebagian di mana arah hubungan sesuai dengan prediksi/hipotesa. Sedang empat hipotesa lain terdukung sepenuhnya oleh data.

Tabel 2. Hasil uji instrumen

\begin{tabular}{|llll}
\hline Human resource practices: $\lambda$ : 0,659- 0,835 & Cronbach's a:0,898 & CR:0,.916 & AVE: 0,579
\end{tabular}

Perusahaan kami berupaya mencocokkan karyawan dengan tuntutan pekerjaan

Kami memperlakukan karyawan sebagai sumber daya yang paling bernilai

Kami memberikan pelatihan untuk setiap karyawan

Kami menekankan pada kepuasan karyawan

Kami mampu mendorong motivasi kerja karyawan

Kami memberikan upah yang pantas sesuai dengan kinerja

Kami memberikan bonus khusus bagi karyawan yang sangat rajin

Kami memberikan masukan bagi karyawan untuk meningkatkan kinerjanya

Kinerja usaha/business Performance: ג:0,611-0,804 Cronbach's a:0,709 CR: 0,795 AVE:0,50

Kami puas dengan kinerja perusahaan

Perusahaan kami lebih untung dibanding pesaing

Perusahaan kami tumbuh lebih cepat dari pesaing kami

Perusahan kami lebih sukses dalam mepertahankan pelanggan

dan meraih pembelian ulang dibanding pesaing

Orientasi pasar/Market orientation: $\quad \lambda:$ 0,546-0,749 Cronbach's a:0,880 CR:0,811 AVE:0,460

Kepuasan konsumen merupakan tujuan strategis kami*

Kami yakin bahwa perlu untuk mengamati perubahan lingkungan utk mengetahui pengaruhnya terhadap kebutuhan konsumen

Mencari dan identifikasi kebutuhan pasar seharusnya menjadi proses yang berkelanjutan

Strategi yg diarahkan pada pencapaian keunggulan bersaing seharusnya didasarkan pada pemahaman

kebutuhan konsumen

Tujuan kami adalah untuk memuaskan kebutuhan dan keinginan konsumen

lebih baik dari pesaing

Sangat penting untuk mengetahui kecenderungan-kecenderungan dalam

lingkungan untuk mengembangkan strategi bersaing

Kami bersatu padu dalam melayani kebutuhan konsumen

Manajer harus memahami kontribusi setiap kegiatan dalam penciptaan nilai bagi konsumen

Orientasi belajar/Learning Orientation: ג:0,659-0,785 Cronbach's a: 0,891 CR:0,916 AVE:0,544

jmm.unram.ac.id 


\title{
Jurnal Magister Manajemen Unram Vol. 7, No 3. September 2018 \\ NATIONALY ACCREDTTED JOURNAL - DECREE NO. 21/E/KPT/2O18
}

\begin{abstract}
Kemampuan kami untuk belajar adalah kunci keunggulan bersaing kami
Belajar adalah kunci untuk peningkatan/perbaikan

Belajar adalah kunci untuk menjamin keberlangsungan usaha

Terdapat kesamaan tujuan di dalam perusahaan

Semua karyawan berkommitment pada pencapaian tujuan perusahaan

Semua karyawan menganggap dirinya sebagai mitra dalam mencapai tujuan

Kami tidak khawatir untuk melakukan refleksi kritis terhadap asumsi kami tentang konsumen

Karyawan menyadari bahwa mereka harus mengevaluasi terus menerus

tentang persepsi mereka terhadap pasar.

Kreatifitas/creativity: $\lambda: 0,653-0,823$ Cronbach's a:0,780 CR:0,836 AVE:0,465

Produk kami sangat istimewa

Produk kami sangat jauh berbeda dari produk-produk sebelumnya

Produk kami sangat menarik

Produk kami sangat berbeda dibanding produk pesaing kami

Dibanding pesaing, produk kami lebih sesuai dengan kebutuhan dan keinginan konsumen

Dibanding pesaing, produk baru kami lebih berguna bagi konsumen

*Item dikeluarkan
\end{abstract}

Pengaruh Learning orientation terhadap kreatifitas dan kinerja usaha (H1 dan H2)

Hasil uji hipotesa menunjukkan bahwa learning orientation tidak berpengaruh signifikan terhadap kreatifitas UMKM. Hal ini menunjukkan bahwa komitmen untuk belajar di dalam perusahaan maupun belajar dari konsumen/pasar sebagai pangkal untuk menumbuhkan kreatifitas di dalam perusahaan. Hasil ini bertolak belakang dengan temuan dari Wang et al. (2008) yang mengatakan bahwa orientasi ini menjadi penentu munculnya ide-ide kreatif. UMKM dalam penelitian ini tampaknya belum kuat berfokus pada belajar, belum memiliki sumber daya manusia yang berorientasi kuat untuk mendapatkan peluang belajar sehingga mereka belum dapat memperoleh pengetahuan dan keahlian kreatif yang lebih tinggi. Komitmen belajar belum mampu memacu kreatifitas; mereka belum mampu menghasilkan ide-ide kreatif yang dapat ditransformasikan menjadi produk produk yang bernilai bagi konsumen, mengevaluasi dan menyesuaikan tawarannya secara kreatif untuk memecahkan masalah konsumen dengan lebih baik dan lebih cepat dari pesaing. Akan tetapi temuan ini membuktikan apa yang telah disebutkan oleh Hirst et al (2011) yang menyatakan hubungan antara learning orientation tidak selalu linier, atau learning orientation tidak otomatis menjamin kreatifitas yang tinggi.

Tabel 3. Hasil uji hipotesa

\begin{tabular}{|c|c|c|c|c|c|c|c|}
\hline \multicolumn{3}{|c|}{ Path } & Estimate & S.E. & C.R. & $\mathrm{P}$ & Label \\
\hline H1. Kreatifitas & $<--$ & $\begin{array}{l}\text { Learning } \\
\text { Orientation }\end{array}$ & ,056 & ,047 & 1,180 & 238 & $\begin{array}{l}\text { Terdukung } \\
\text { sebagian }\end{array}$ \\
\hline $\begin{array}{l}\text { H2. Kinerja } \\
\text { Usaha }\end{array}$ & $<--$ & $\begin{array}{l}\text { Learning } \\
\text { Orientation }\end{array}$ & 300 & 079 & 3,798 & $* * *$ & Terdukung \\
\hline H3. Kreatifitas & $<--$ & $\begin{array}{l}\text { Market } \\
\text { Orientation }\end{array}$ & ,274 & ,073 & 3,775 & $* * *$ & Terdukung \\
\hline
\end{tabular}




\begin{tabular}{|lrl|rrrr|}
\hline & Path & Estimate & S.E. & C.R. & P & Label \\
\hline $\begin{array}{l}\text { H4. Kinerja } \\
\text { Usaha }\end{array}$ & $<--$ & $\begin{array}{l}\text { Market } \\
\text { Orientation }\end{array}$ &, 150 &, 149 & 1,009 & ,313 $\begin{array}{l}\text { Terdukung } \\
\text { sebagian }\end{array}$ \\
H5. Kreatifitas & $<---$ & $\begin{array}{l}\text { Human Resource } \\
\text { Practices }\end{array}$ &, 371 &, 128 & 2,910 &, 004 Terdukung \\
$\begin{array}{l}\text { H6. Kinerja } \\
\text { Usaha }\end{array}$ & $<--$ & $\begin{array}{l}\text { Human Resource } \\
\text { Practices }\end{array}$ &, 070 &, 091 &, 774 &, $439 \begin{array}{l}\text { Terdukung } \\
\text { sebagian }\end{array}$ \\
$\begin{array}{l}\text { H7. Kinerja } \\
\text { Usaha }\end{array}$ & $<--$ & Kreatifitas &, 766 &, 221 & 3,469 & $* * *$ Terdukung
\end{tabular}

Akan tetapi, data menunjukkan bahwa UMKM percaya bahwa belajar menjadi pangkal kesuksesan usaha, ini terlihat dari adanya pengaruh yang kuat dari learning orientation terhadap kinerja usaha. Orientasi ini merupakan kapabilitas organisasi membantu perusahaan untuk mengadaptasikan tawarannya, memadukan dan menggunakan sumber daya yang dimilikinya menciptakan nilai pelanggan yang optimal untuk kinerja usaha yang lebih baik. Orientasi ini secara langsung mampu meningkatkan kinerja usaha walaupun orientasi ini belum cukup kuat mengembangkan kreatifitas UMKM. Hasil ini tidak konsisten dengan penelitian sebelumnya (Sulhaini dkk., 2017).

Pengaruh market orientation terhadap kreatifitas dan kinerja usaha (H3 dan $\mathrm{H} 4$ )

Berbeda dengan learning orientation, market orientation justru memiliki pengaruh kuat terhadap kreatifitas akan tetapi tidak terhadap kinerja usaha. Orientasi terhadap konsumen dan pesaing serta kerjasama internal akan memacu daya kreatifitas di dalam perusahaan. Karyawan berusaha memahami konsumen dan tawaran pesaing yang akan menjadi dasar bagi mereka untuk mengembangkan produk yang lebih baik dari sebelumnya dan pesaing sesuai dengan tuntutan konsumen yang senantiasa dinamis. Orientasi pasar merupakan pangkal dari pengembangan produk yang secara dinamis mengikuti perubahan tuntutan konsumen dan persaingan. Hal ini mengeaskan pendapat dari Alves et al. (2007). Semua dimensi dari orientasi ini membantu perusahaan untuk mendeteksi munculnya ancaman dan peluang dalam lingkungan persaingan yang sangat dinamis. Perusahaan mampu memenuhi kebutuhan konsumen sekaligus menciptakan nilai pelanggan yang superior (Nasution and Mavondo, 2008).

Hasil penelitian ini juga sejalan dengan hasil penelitian sebelumnya. Barrett et al (2005) menunjukkan bahwa semua dimensi dari orientasi ini menyediakan rute kritis bagi kreatifitas perusahaan. Selanjutnya, temuan dari penelitian yang dilakukan oleh Im et al. (2008) menunjukkan bahwa kesemua dimensi orientasi pasar dapat menjamin tercapaianya peningkatan kreatifitas.

Hasil penelitian ini bertentangan dengan hasil penelitian-penelitian terdahulu pada umumnya menemukan bahwa orientasi ini berpengaruh kuat terhadap kinerja usaha (Grinstein, 2008; Sulhaini dkk, 2017; Sulaimiah dan Sulhaini, 2017). Market orientation menjadikan perusahaan 


\section{Jurnal Magister Manajemen Unram ～Vol. 7, No 3. September 2018 \\ NATIONALY ACCREDTED JOURNAL - DECREE NO. 21/E/KPT/2O18}

supaya mendeteksi dan memonitor lingkungan persaingan agar dapat secara kreatif memuaskan konsumennya. Orientasi pasar secara luas difahami sebagai orientasi yang mampu mengarahkan perusahaan untuk mendapatkan pengetahuan dan bahwa ide-ide untuk inovasi dapat berasal dari konsumen agar tidak ada ide yang tidak tepat diimplemensikan sebagai inovasi Hal ini disebabkan karena orientasi tersebut dapat mendorong komitmen perusahaan terhadap konsumennya. Penelitian ini menunjukkan bahwa orientasi ini tidak berpengaruh langsung terhadap kinerja usaha. Orientasi ini tidak secara langsung menentukan kinerja usaha, sekalipun orientasi ini menekankan pada pemahaman pada dinamika keinginan/kebutuhan konsumen dan strategi pesaing tetapi tidak secara langsung menjamin kinerja usaha. Hal ini sejalan dengan temuan dari Sulhaini dan Sulaimiah (2017) yang menjelaskan bahwa fokus pada pemuasan kebutuhan konsumen (bagian dari dimensi pertama dari orientasi pasar) saja tidak cukup untuk meraih kinerja usaha yang tinggi bila perusahaan cenderung passive dalam menjalankan usahannya.

Pengaruh human resource practice terhadap kreatifitas dan kinerja usaha (H5 dan H6)

Penelitian ini menunjukkan bahwa human resource practices berpengaruh signifikan terhadap kreatifitas. Hal ini menegaskan bahwa semakin baik pengelolaan sumber daya manusia akan semakin mendorong kreatifitas karyawan dalam mengembangkan dan menciptakan produk baru yang lebih baik. Karyawan dipandang sebagai sumber daya yang terpenting sehingga komitmen untuk menjaga kepuasan dan motivasi kerja mereka menjadi strategi yang tepat untuk menguatkan daya kreatifitasnya. Komitmen itu ditunjukkan dengan memberikan pelatihan dan upah/bonus yang sesuai akan menghasilkan karyawan yang mencurahkan waktu dan tenaganya untuk berkreasi. Hal ini menguatkan hasil penelitian dari Nasution and Mavondo (2008) dan MuñozDoyage and Nieto (2012).

Hasil penelitian ini juga menunjukkan bahwa human resource practices memicu kreatifitas tetapi tidak secara langsung menentukan kinerj usaha. Praktek tersebut memicu kreatiftas pada level perusahaan dan kinerja usaha (Beugelsdijk, 2008). Penelitian ini menegaskan bahwa human resource practices seperti pelatihan, pengupahan, peningkatan kepuasan dan motivasi kerja yang baik tidak menjamin kinerja usaha. Hasil ini sejalan dengan penelitian sebelumnya (Sulaimiah dan Sulhaini, 2017).

Pengaruh kreatifitas terhadap kinerja usaha (H7)

Penelitian ini menunjukkan bahwa kreatifitas berpengaruh kuat dan langsung terhadap kinerja usaha. Semakin kreatif perusahaan dalam menciptakan produk baru yang lebih istimewa, sempurna dan lebih baik dari pesaing menjadi jaminan bagi kesuksesan produk baru/hasil kreasi di pasar sehingga membawa kinerja usaha yang lebih tinggi. Dengan demikian UMKM yang kreatif akan memiliki kemampuan yang lebih tinggi dalam mengembangkan produk dan strategi pemasarannya dan mampu meraih kinerja yang lebih baik. Hasil ini mendukung pendapat dari Slater et al. (2010).

Market orientation dan human resource practices tidak berpengaruh langsung terhadap kinerja usaha tetapi melalui pengaruh keduanya terhadap kreatifitas (market orientation - kreatifitas kinerja usaha: $0.150 \times 0.766=0.115$; human resource practices - kreatifitas - kinerja usaha: $0.070 \times$ 


\section{Jurnal Magister Manajemen Unram Vol. 7, No 3. September 2018 \\ NATIONALY ACCREDTED JOURNAL - DECREE NO. 21/E/KPT/2O18}

$0.766=0.053$ semua signifikan pada $p: 0.000$ ). Ini menunjukkan orientasi pasar yang kuat pada akhirnya akan berdampak positif terhadap kinerja usaha melalui kemampuanya meningkatkan daya kreatifitas pada pengembangan produk maupun pemasarannya, karena orientasi tersebut memberikan peluang bagi perusahaan untuk menemukan ide-ide kreatif yang menjamin kesuksesan penjualan produk. Selain itu, human resource practices menjamin karyawan bekerja dengan motivasi kuat untuk berkreasi secara berkelanjutan. Hasil ini menunjukkan bahwa human resource practices dapat meningkatkan kinerja usaha bilamana practices tersebut diarahkan pada peningkatan kreatifitas karyawan. Secara singkat, dapat dikatakan bahwa semakin kuat orientasi pasar dan human resource practices semakin kuat kreatifitas dan semakin tinggi kinerja usaha yang dapat diraih.

\section{CONCLUSION}

Penelitian ini bertujuan untuk memberikan kontribusi pada literature dengan memberikan penjelasan terkait bagaimana human resource practices dan budaya organisasional mempengaruhi kreatifitas dan kinerja usaha UMKM. Kreatifitas telah banyak diteliti di kalangan perusahaan besar sementara kreatifitas di perusahaan kecil belum banyak difahami. Penelitian ini memberikan penjelasan yang komprehensif luas terkait peranan strategi human resource practices, budaya organisasi (market orientation dan learning orientation) terhadap kreatifitas dan kinerja usaha UMKM.

Market orientation dan learning orientation mempengaruhi kreatifitas dan kinerja usaha dengan cara yang berbeda. Learning orientation tidak berpengaruh kuat terhadap kreatifitas tetapi berpengaruh langsung terhadap kinerja usaha. Sedangkan human resource practices memiliki pengaruh yang sama dengan market orientation. Di mana keduanya tidak berpengaruh langsung terhadap kinerja usaha secara langsung tetapi melalui pengaruhnya terhadap kreatifitas. Market orientation dan human resource practices menjamin kinerja usaha yang tinggi melalui pengaruhnya terhadap peningkatan kreatifitas. Orientasi menjadi sumber inspirasi ide-ide kreatif karena adanya orientasi kepada konsumen dan pesaing memberikan peluang bagi UMKM untuk menemukan ide. Selanjutnya, human resource practices menjaga/menguatkan motivasi karyawan untuk berkreasi secara berkelanjutan, lebih cepat dan lebih unggul dari pesaing. Hal ini menciptakan nilai pelanggan yang maksimal atau keunggulan bersaing yang lebih kuat dan menjadi jaminan kesuksesan usaha/kinerja usaha.

\section{IMPLIKASI MANAJERIAL}

Hasil penelitian memberikan implikasi manajerial yang sangat jelas.

a. Implementasi learning orientation menjamin kinerja usaha. Komitmen perusahaan untuk belajar dengan memberi peluang bagi karyawan untuk belajar dan sharing pengetahuan dapat mendorong kinerja usaha.

b. Implementasi market orientation berarti memperkuat kreatifitas karena orientasi ini menjadi sumber ide-ide kreatif. Semakin dekat perusahaan dengan konsumennya dan semakin baik pemahaman terhadap strategi pesaing dan kerjasama internal maka akan semakin tinggi kreatifitas individu/tim/perusahaan. 


\section{Jurnal Magister Manajemen Unram ～Vol. 7, No 3. September 2018 \\ NATIONALY ACCREDTED JOURNAL - DECREE NO. 21/E/KPT/2O18}

c. Implementasi human resource practices yang mengarah pada peningkatan motivasi kerja karyawan akan menghasilkan karyawan yang memiliki kreatifitas tinggi secara berkelanjutan.

d. Kreatifitas yang tinggi (melalui implementasi penguatan orientasi pasar dan human resource practices) akan memperbesar peluang perusahaan untuk meraih kesuksesan penjualan/kinerja usaha.

\section{REKOMENDASI BAGI PENELITIAN SELANJUTNYA}

Penelitian ini telah memberikan bukti empiris terkait anteseden dari kreatifitas dan dampaknya terhadap keinerja usaha di kalangan UMKM. Akan tetapi tidak ada penelitian yang sempurna dalam arti masih terdapat beberapa hal yang masih perlu disempurnakan oleh penelitian selanjutnya.

a. Penelitian ini tidak menguji hubungan antar kedua orientasi budaya (learning dan market orientations) dan hubungan antara keduanya dengan human resource practices.

b. UMKM yang menjadi responden masih terbatas di kota madya Mataram, penelitian selanjutnya diharapkan dapat memperluas wilayah penelitian dan melibatkan lebih banyak responden di berbagai sector industri.

c. Penelitian ini menggunakan instrument yang disusun dengan mengadopsi item-item pengukuran dari penelitian sebelumnya dengan subyek yang sangat mungkin tidak memiliki karakteristik yang sama dengan UMKM di Lombok/Indonesia. Penelitian selanjutnya diharapkan pula dapat mengembangkan item-item pertanyaan yang secara khusus diangkat dari sebuah penelitian pendahuluan untuk memahami karakteristik UMKM di Lombok/Indonesia.

\section{DAFTAR PUSTAKA}

Amabile, T.M. (1988) 'A model of creativity and Innovation in Organisations', Research in Organisational Behaviour, 10, 123-167.

Alves, J., Marques, M. J., Saur, I, Marques, P. (2007) ' Creativity and Innovation through multidiciplinary and multisectoral cooperation, Creativity and Innovation Management, 16 (1), 27 - 34. Baker, W.E. and Sinkula, J.M. (2009) 'The complementary effects of market orientation and entrepreneurial orientation on profitability in small business', Journal of Small Business Management, 47(4), $443-464$

Barrett, H., Balloun J.L. and Weinstein, A. (2005) ' The impact of creativity on performance in nonprofits' Int. J. Nonprofit Volunt. Sect mark. 10, 213-223.

Beugelsdijk, S. (2008). Strategic human resource practices and product innovation, Organisation Studies, 29, (6), $821-847$.

Burroughs, J. E., Dahl, D.W., Moreau, P. Chattopadhyay, A. And Gorn, G.J., (2011) 'Facilitating and Rewarding Creativity During New Product Develeopment, Journal of Marketing, 75, July, 53 - 67.

Cropley, D.H., Kaufman, J.C. and Cropley, A.J. (2011) 'Measuring creativity for innovation management', J. Technol. Manag. Innov. 6 (3), 13 - 29. 


\section{Jurnal Magister Manajemen Unram}

Ḉokpekin, Ö. and Knudsen, M. P. (2012) ' Does Organizing for Creativity Really Lead to Innovation?' Creativity and Innovation Management, 21 (3), 304 - 314.

Grinstein, A. (2008) 'The relationships between market orientation and alternative strategic orientations' European Journal of Marketing, 42 (1/2), 115-134.

Gong, Y., Huang, J., and Farh, J. (2009) 'Employee learning orientation, transformational leadership, and employee creativity: the mediating role of employee creatve self-efficacy" Academy of Management Journal, 52 (4), 765 - 778.

Hair, J.F., Black, W.C, Babin, B.J., Anderson, R.E., and Tatham, R.L. (2006). Multivariate Data Analysis. New Jersey: Pearson Education International.

Hansen, D.J., Lumpkin, G.T., and Hills, G.E.(2011), A multidimensional examination of a creativitybased opprotunity recognition model' International Journal of Entrepreneurial Bheaviour E Research, 17 (5), 515-533.

Hirst, G., Knippenberg, D.V and Zhou, J. (2009) 'A cross level perspective on employee creativity: a goal orientation, team learning behaviour, and individual creativity, Academy of Management Journal, $52(2), 280-293$.

Hsu, Y. (2016) “Innovation and competitive edge: effective designer management in Chinese SMEs', The International Journal of Organisational Innovation, 8 (3), .64 - 78.

Im S. And Workman, J.P. (2004) 'Market orientation, creativity and New Product Performance in High-Technology Firms', Journal of Marketing, 68 (Apri), 114-132.

Im, S., Hussain, M. And Gupta, S. (2008) 'Testing interaction effects of the dymensions of market orientation on marketing program creativity', Journal of Business Research, 61, 859 - 867.

Im, S., Montoya, M.M. and Workman, J.P. (2013) 'Antecedents and consequences of creativity in product innovation teams', J. Prod. Innov Manage., 30 (1), 170-185.

Mavondo, F.T., Chimhanzi, J., Stewart, J., (2005)' Learning orientation and market orientation', European Journal of Marketing, 39 (11/12), 1235-1263

Muñoz-Doyage, M.F. and Nieto, M. (2012) 'Individual creativity performance and the quality of interpersonal relationships, Industrial Management and data Systems, 112 (1),.125-145.

Nasution, H.N. and Mavondo, F.T., (2008);. 'Organisational Capabiliities: Antecedents and Implications for customer value, European Journal of Marketing, 42 (3/4),. 477-501.

Sanzo, M.J., Santos, L.M., Vazquez, R. and Alvares, L.I. (2003) 'The Role of Market Orientation in Business Dyadic Relationships: Testing an Integrator Model', Journal of Marketing Management, 19, 73-107

Sinkula, J. M., Baker, W.E., and Noordwier, T., (1997) 'A framework for market-based organizational learning: Linking values, knowledge, and behavior' Journal of the Academy of Marketing Science, September, 25-35,

Slater S.F., and Narver, J.C. (1995) 'Market orientation and the learning organisation, Journal of Marketing, 59, July, 63-74

Slater, S.F., Hult, G.TM, and Olson, E.M. (2010) ' Factors infleuncing the relative importance of marketing strategy creativity and marketing strategy implementation effectiveness' Industrial Marketing Management, 39,.551-559.

Suh, T., Bae, M., Zhao, H., Kim, S.H., Arnold, M. J. (2010) ' A multi level investigation of international marketing projects: the roles of experiential knowledge and creativity of performance' Industrial Marketing Management, 39, 211 - 220. 
Suh, T., Jung, J.C and Smith, B.L. (2012) 'Learning creativityin the client-agency relationship' The learning organization, 19.(.5), 428-439.

Sulaimiah dan Sulhaini, (2017) "How do Entrepreneurial Human Resource Practices Determine Small Firm Enterprice Firms' Perfromance? International Research Journal of Business Studie. 9 (3), 133-146

Sulhaini dan Sulaimiah, (2017) 'Assessing value co-creation and new product success from cultural orientations and relationship marketing perspectives', Journal of Relationship Marketing 16 (1), 21-39.

Sulhaini,Rusdan, Sulaimiah, Baiq Ismiwati, Rahman Dayani, Rini Anggriani, (2017), 'Pengaruh Market dan Learning Orientations terhadap Relational Capability dan Kinerja Usaha UMKM di Kota Mataram', JMM UNRAM, Maret, 40-53.

Trigo, A. (2013) ' Mechanisms of Learning and Innovation Performance: The Relevance of Knowledge Ssharing and Creativity for Non-Technological Innovation' International Journal of Innovation and technology Management' Vol. 10 No. 6, DOI: 10/1142/S021987701340282.

Wang, E. T.G. and Wei, H. (2005) 'The importance of market orientation, learning orientation and quality orientation capability in TQM: an example from Taiwanese software industry', Total Quality Management, Vol. 16 No. 10, pp.1161 - 1177

Wang, Q., Brandford, K., Xu, J., Weitz, B. (2008) ' Creativity in buyer-seller relationships: the role of governance', International Journal of Research in Marketing, vol. 25, pp. 109 -118.

Widarjono, A., 2010, Analisis Statistika Multi Variat Terapan, UPP STIM YKPN, Yogyakarta 